\title{
Arguments and modifiers in deverbal nominals: Romanian Genitives and de- PPs
}

\section{Elena Soare}

Université de Paris 8 \& CNRS SFL

elena.soare@univ-paris8.fr

\section{Isabelle Roy}

Université de Nantes \& CNRS LLing

isabelle.roy@univ-nantes.fr

Received: 15-03-21

Accepted: 30-09-21

Published: 22-02-2022

How to cite: Elena Soare \& Isabelle Roy. 2022. Arguments and modifiers in deverbal nominals: Romanian Genitives and de-PPs. RLLT17, eds. Ora Matushansky, Laurent Roussarie, Michela Russo, Elena Soare \& Sophie Wauquier. Special issue of Isogloss Open Journal of Romance Linguistics 8(2)/2, 1-17.

DOI: https://doi.org/10.5565/rev/isogloss.133

\begin{abstract}
This paper addresses the distribution of Genitives and PPs in deverbal nominalizations with a particular focus on Romanian -tor nominals that express agents, e.g., vânzător 'seller', and instruments, e.g., tocător 'shredder'. The issue of the distribution of Genitives is central to understanding the argumental structure properties of deverbal nominalizations in Romanian, and cross-linguistically. Derived nominals expressing agents and instruments have been and continue to be the subject of much controversy in the literature with respect to whether they (or at least some of them) involve an argument structure. We argue that the existence of an argumental Genitive in Romanian provides strong support for views that propose that (at least a subclass of) agent nominals have argument-structure properties. However, we also show that a proper understanding of the distribution of Genitive case-marked complements and PPs bears upon their interpretive nature, and more particularly on their specific vs. non-specific interpretation.
\end{abstract}


Keywords: deverbal nominals, agent and instrument-denoting nominals, argument structure, event structure, argument, modifier, genitive, PP.

\section{Introduction}

\subsection{Background}

A common view on deverbal nominals is that they are split into two distinct classes depending on whether or not they exhibit argument structure and event structure properties (Chomsky 1970, Grimshaw 1990, Borer 2013, a.o). Complex Event Nominals (CENs, Grimshaw 1990), also termed Argument Structure Nominals (AS-Ns, Borer 2013), exhibit both an argument structure and an event structure which are assumed to be inherited directly from an underlying verbal structure: e.g. the destruction of the city by the enemy in two hours. By opposition, nominals that lack both an argumental structure and an event structure, often termed Referential Nominals (R-Ns), are assumed to be derived directly from roots, even though, on the surface at least, they seem to relate to a verb: e.g., this huge building (*of..., *by ..., *in ...) (Grimshaw 1990, Borer 2013).

The question whether a similar AS-N / R-N dichotomy also exists among agent and instrument denoting derived nominals has been the subject of much debate in recent literature, and going back to Chomsky's (1970) Remarks on Nominalization. For Chomsky, all individual-denoting nominals (including what we call agents, and Chomsky did not address instruments specifically), are non-derived and do not have an argument structure. This includes e.g., the general secretary of the party, the assistant vicechancellor of the university, as well as nominals that may be descriptively associated with a lexical verb (e.g., director (direct-), diver (dive-), owner (own-)). Borer (2013) takes a similar position. We refer the reader to Roy \& Soare (2020) for details of their argumentation which we are not going to develop here.

Other studies, starting with Rappaport Hovav \& Levin (1992), van Hout \& Roeper (1998), and later on Alexiadou \& Schäfer (2008, 2010), McIntyre (2014) and Roy \& Soare $(2013,2014,2020)$, have pointed to the lack of homogeneity in agent and instrument denoting deverbal nominals. Leaving aside significant differences between these specific analyses, they all agree on the fact that (at least a subclass of) deverbal -er nominals are syntactically derived from a verbal structure, and exhibit argument and event structure properties.

Rappaport Hovav \& Levin (1992) first proposed that the eventive reading of -er nominals, forced by event-related modifiers like the adjectives constant and frequent, is correlated with argument realization (via the insertion of an argumental of-phrase). Hence, they point that while phrasal formations such as mower of the lawn, saver of lives receive an eventive interpretation, synthetic compounds such as lawn mower, lifesaver, firefighter, which do not involve an argument, never allow the eventive interpretation. Only phrasal nominals are AS-Ns. They also note that while synthetic compounds can denote an agent or an instrument (e.g., branch cutter), phrasal nominals denote only agents (e.g., cutter of branches). See also van Hout \& Roeper (1998) and Roy et al. (2016).

In a more drastic move, Alexiadou \& Schäfer (2010) have proposed that all derived -er nominals are AS-Ns. Some are interpreted as episodic, while others are dispositional; the latter include instruments. On the basis of interpretational and morphological properties, and especially verbal derivational morphology (e.g. humidi- 
In turn, instruments (1c) are R-Ns. They involve neither an eventive structure nor an argumental structure and are assumed to be root-derived: ${ }^{1}$

\section{Instruments (R-Ns): [NP N -er [C=N Root ]]}

Empirical evidence for the absence of eventive and argumental structure in instruments comes from (internal) event related adjectival modification, e.g., big-type adjectives ${ }^{2}$, which is altogether unavailable in instruments (see Roy \& Soare 2013, 2014, 2020 for details of the argumentation). More precisely, BAs can have an eventive interpretation (modification of the internal event) when they modify dispositional agents but not when they modify instruments; cf., examples (6) for French and (7) for Romanian. In (6a) and (7a), with dispositional agents, the internal event modification is available. Dispositional nominals relate to an eventuality that can remain unactualized. This is not the case, however, with instruments. In French (6b), the eventive reading is simply unavailable. In Romanian (7b), the prenominal position of mare 'big' (as opposed to the post-nominal position) entails an event related interpretation, which leads to complete ungrammaticality:

a. Nous avons trouvé un gros vendeur de voitures.

we have found a big seller of cars

$\rightarrow$ big person who sells cars

$\rightarrow$ person who can sells a lot of cars (e.g. lots of cars are for sale)

b. Nous avons trouvé un gros broyeur de végétaux. R-N; instrument

we have found a big shredder of plants

$\rightarrow$ big machine that shreds plants

$\nrightarrow$ a machine that can shred a lot of plants
a. Am găsit un mare vânzător de mașini.
AS-N; agent have found a big seller of cars
$\rightarrow$ big person who sells cars
$\rightarrow$ person who can sell a lot of cars (e.g. lots of cars are for sale)
b. *am găsit un mare tocător de vegetale
$\mathrm{R}-\mathrm{N}$; instrument
have found a big shredder of vegetables

Assuming, as commonly the case in the literature, that internal eventive modification signals the presence of an internal event structure, and that internal event structure is correlated with argument structure properties, we must conclude that instrument -er nominals are R-Ns. PPs that occur with instruments are thus modifiers and cannot be arguments. ${ }^{3}$

1 In this view, arguments cannot be projected directly from roots, but they are assumed to be introduced by dedicated functional heads in the structure, in agreement with Borer (2013).

2 Modification with frequent adjectives (FAs) distinguishes between episodic and dispositional agent -er nominals, while modification with big adjectives (BAs) distinguishes between dispositional agent -er nominals and instruments (Roy \& Soare 2014, 2020).

3 In further support, note that in French $d e$-PPs with instruments can be replaced with $\grave{a}-$ PPs which are clearly adjuncts: un broyeur à végétaux (lit. a shredder at plants) (see Roy \& Soare 2014). Moreover, in both French and Romanian, $d e$-PPs with instruments can be separated from 
The goal of this paper is to address the distribution of argumental Genitives and PPs in Romanian deverbal -tor nominals as an insight into the argument structure properties of these nominal formations.

\subsection{Issue}

An issue arises concerning the distribution of the argumental Genitive in Romanian. Across the languages that have deverbal nominals, we find two possibilities to express arguments and modifiers of AS-Ns, namely with PPs (e.g., of-phrase in English, dephrase in Romanian and $d e$-phrase in French) or with Genitives:

(8) a. [The enemy's] destruction [of the city] [in two hours]

$$
\text { Arg-GEN Arg-PP Modif-PP }
$$

b. [Last year's] destruction [of the city] [by the enemy]

$$
\text { Modif-GEN Arg-PP Arg-PP }
$$

(9) Distrugerea [orașului] [de către inamic] [în două ore]

destruction-the city.GEN by part enemy in two hours

$$
\text { Arg-GEN Arg-PP Modif-PP }
$$

(10) La destruction [de la ville] [par les ennemis] [en deux heures] the destruction of the city by the enemies in two hours

$$
\text { Arg-PP Arg-PP Modif-PP }
$$

In languages such as French, where case is not morphologically marked, de-PPs do not discriminate, on the surface at least, between an argument and a modifier:

(11) La destruction [de la ville] [de l'année dernière]

the destruction of the city of the.year last

'last year's destruction of the city'

Thus, in French, arguments of episodic and dispositional agent -eur AS-Ns are realized as $d e$-PPs, similarly to the modifiers with instruments (R-Ns) (12):

a. episodic AS-N agent - eur nominals

$$
\begin{aligned}
& \rightarrow \text { le vendeur de la voiture } \\
& \text { the seller of the car } \\
& \text { 'the seller of the car' } \\
& \rightarrow \text { le vendeur de voitures } \\
& \text { the seller of cars } \\
& \text { 'the car-seller' } \\
& \rightarrow \text { le broyeur de végétaux } \\
& \text { the shredder of plants } \\
& \text { 'the plant-shredder' }
\end{aligned}
$$$$
\text { b. dispo AS-N agent -eur nominals }
$$$$
\text { c. instrument } \mathrm{R}-\mathrm{N} \text {-eur nominals }
$$

Romanian has a Genitive case, and thus presents a slightly different situation. Arguments of AS-Ns can be realized as a Genitive (under conditions that we are going to

the nominal head: un distributeur automatique d'argent (lit. a distributor automatic of money)/ un transmițător electric de semnale (lit. a transmitter electric of signals) unlike in dispositional agent nominals (see section 4 for further discussion). 
discuss in the rest of the paper) (13a); while modifiers are always expressed by de-PPs, and never take the Genitive (13b-c).

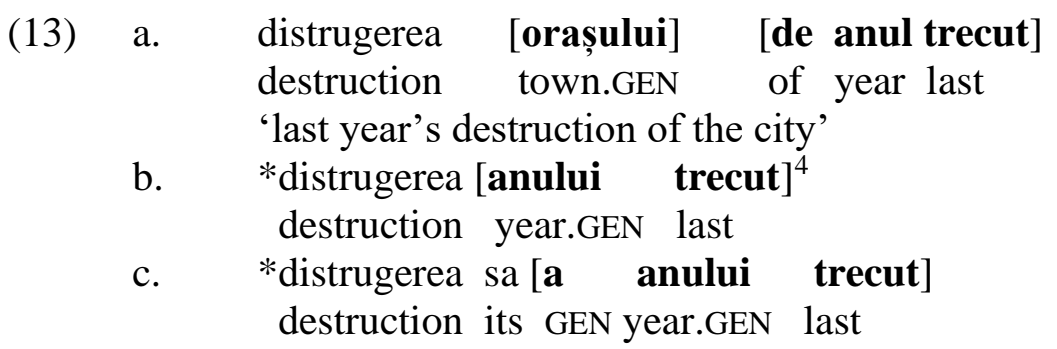

Since agent -tor nominals are AS-Ns and instrument -tor nominals are R-Ns (following the results of Roy \& Soare 2020 for Romanian), we would expect argumental Genitives in the former case and not in the latter. This expectation, however, is not met. A close look at the distribution of Genitives reveals that while it is the only option with episodic agent nominals (14a); it is ungrammatical both with dispositional agent nominals (14b) and instruments $(14 \mathrm{c})$ :

$$
\begin{aligned}
& \text { a. episodic AS-N agent -tor nominals } \rightarrow \text { vânzătorul mașinii / *de mașini } \\
& \text { seller.the car.GEN of cars } \\
& \text { 'the seller of the car' } \\
& \text { b. dispo AS-N agent -tor nominals } \rightarrow \text { vânzătorul de mașini / *mașinii } \\
& \text { seller.the of cars car.GEN } \\
& \text { 'the car-seller' } \\
& \text { c. instrument R-N -tor nominals } \rightarrow \text { tocătorul de vegetale/*vegetalelor } \\
& \text { shredder.the of plants plants.GEN } \\
& \text { 'the plant-shredder', }
\end{aligned}
$$

The absence of argumental Genitives in instrument denoting -tor nominals is not surprising since they are R-Ns, and thus do not support arguments (14c). However, the puzzle is to explain the distribution of argumental Genitives with agent denoting nominals. Although all of them are AS-Ns, cf. (2), Genitives appear with a subclass only, namely episodic agent -tor nominals (14a), and not dispositional agent -tor nominals (14b). Why is the Genitive out with dispositional agent -tor AS-Ns?

Differences in argument realization among -er nominals have also long been noted for English. Episodic and dispositional agents do not pattern together in English. The former, which are phrasal, project an of-PP argument (e.g., saver of lives), while the latter, which are synthetic compounds, involve a form of incorporation (e.g., lifesaver). In Alexiadou \& Schäfer's (2010) approach, since all -er nominals are AS-Ns, and hence argument projecting structures, the difference is accounted for by stipulating additional restrictions on the argument structure in the context of the dispositional aspectual head (Asp DISPO). Specifically, they assume Asp DISPO $_{\text {to }}$ prevent the projection of internal arguments in both dispositional and instrument -er nominals. Only nominals involving AspePISO project an internal (quantized) argument.

$4 \quad$ Independently, Romanian, like other Romance languages, does not accept two Genitives in a single DP. However, the ban on Genitive with modifiers goes beyond this restriction, as shown by (c). 
The extension of this analysis to the Romanian paradigm, could, a priori, seem feasible. The absence of the Genitive case with dispositional agents would be derived from the absence of an internal argument altogether, in relation to the presence of the aspectual projection Asp DISPO. Only episodic agent nominals would project an internal argument, associated with Genitive case marking; while de-PPs in dispositional agents, as well as instruments, would no longer be internal arguments. However, there are two reasons not to do so. First, Romanian dispositional agents and instruments do not have the same internal structure; dispositional agents are AS-Ns, and thus project an internal argument; while instruments are R-Ns (cf. Roy \& Soare 2020). Second, such a view would simply miss on the fundamental generalization that case marking is correlated with specificity in the grammar of Romanian. Instead, we will argue that the correlation between case marking and specificity, together with the correlation between specific internal event and episodic reading derives, without resorting to any additional stipulations, the interpretive differences between episodic and dispositional agent nominals, as well as the restricted distribution of the Genitive. As a consequence, dispositional agents involve an incorporated PP argument, while instruments involve a PP modifier.

We will first address the distribution of the Genitive in episodic agent nominals and instruments, and show that it supports the original distinction between AS-Ns and RNs among -tor nominals (Section 2). We will then address dispositional agent nominals, and argue that there is a correlation between Genitive case and specificity in Romanian leading to an impossibility to use Genitives with dispositional nominals (Section 3). Finally, we will present our analysis of dispositional agent nominals as involving pseudoincorporated arguments (Section 4), and make some concluding remarks on crosslinguistic variations (Section 5).

\section{Support for the AS-N / R-N split in -tor nominals}

The distribution of argumental Genitive provides clear support for a view in which derived -tor nominals are split into at least two groups, AS-Ns and R-Ns, as in Roy \& Soare's (2020) account. Genitives and de-PPs are in complementary distribution in two of the three classes under discussion: episodic agent nominals and instruments. Episodic agent -tor nominals take argumental Genitive DPs, and can never be construed with dePPs (15)-(16). Importantly, in (15a-16a), the Genitive can only be interpreted as an internal argument:

(15) a. Aducătorul scrisorilor va primi o recompensă. carry-er letter.DET.GEN will receive a reward 'The carrier of the letter will receive a reward'.

b. *Aducătorul de scrisorile va primi o recompensă. carry-er of letters.DET will receive a reward

(16) a. vindecătorul acestui bolnav healer-the this.GEN sick-person

b. *vindecătorul de acest bolnav healer-the of this sick-person 'the healer of this sick person' 
By contrast, instrument -tor nominals do not take argumental Genitives. Although it is possible to find Genitives with instruments (e.g. copiator in (17)), when available they can never be interpreted as an internal argument. Thus, while examples in (17) are attested, they cannot have the same interpretation as the examples in (15)-(16). In (17), the Genitive can only be interpreted as a possessive. Hence in (17a) the nominal copiatorul articolului (lit. copy-er article.GEN) cannot mean 'the copy machine that copied the article', but 'the copy machine that belongs to the article', which may appear contextually weird. Similarly, in (17b), the only reading available is one in which the copy machine belongs to the department, and the argumental reading is excluded.
a. Copiatorul articolului s-a stricat. copy-er article.GEN se-has broken
$\rightarrow$ 'the copy-machine that belongs to the article is broken'
$\rightarrow$ 'the copy-machine that copied the article is broken'
b. Copiatorul catedrei s-a stricat.
copy.er.the department. GEN se.has broken
$\rightarrow$ 'the copy machine of the department is broken'
$\rightarrow$ 'the copy machine that copied the department is broken'

Possessive Genitives are not related to internal argumental structure properties. The absence of argumental Genitive, which, to the best of our knowledge, has never been addressed before, follows directly from the absence of argument structure with instruments (Roy \& Soare 2020).

By contrast, instrument -tor nominals take de-PPs (18). And compare with episodic agent -tor nominals in (15)-(16).

transmiţătorul de semnale s-a stricat.

transmitter.the of signals se-has broken

'The transmitter of signals is broken'.

The mere co-existence of argumental Genitives and de-PPs in the grammar of deverbal nominals in Romanian confirms the split between AS-N and R-N -tor nominals. ${ }^{5}$

As already stated in the introduction, an evident expectation would be that the presence of Genitive arguments signals AS-Ns; whereas the presence of $d e$-PPs signals R-Ns. However, because dispositional agent nominals also take de-PPs, the situation is manifestly more complex. The distribution of Genitives and $d e$-PPs in itself cannot constitute a sufficient empirical clue to identify arguments and non-arguments in Romanian deverbal nominals: while some arguments are marked with the Genitive, others are PPs; and while some PPs are arguments, others are mere modifiers.

To understand the distribution of Genitives and PPs, let us turn to dispositional agent nominals.

\footnotetext{
5 And the mere existence of an argumental Genitive in Romanian -tor nominals argues against the Chomsky/Borer view that treats all individual-denoting nominals as R-Ns altogether.
} 


\section{Genitive case and specificity}

The issue with dispositional agent -tor nominals, as already stated, is that they are AS-Ns (Roy \& Soare 2020) but they cannot take Genitive arguments and instead take de-PPs. In that respect, on the surface at least, they resemble instruments, i.e. they behave like -tor nominals that do not support arguments (cf., paradigm in (14)). Dispositional agent nominals, however, are different from episodic agent nominals, in the fact that they take non-specific arguments. Specificity, we will argue, is precisely what licenses Genitive case marking.

There is a simple reason for that. Case is morphologically marked on determiners in Romanian. In the language, non-specific arguments are expressed by bare plurals. They lack a D (Dobrovie-Sorin \& Giurgea 2015, among others). Consequently, non-specific arguments can never be case-marked (in the absence of an overt D). Case marked definite and indefinite DPs are interpreted as specific. This is a general constraint on argumental and non-argumental case in Romanian. Consider, for instance, argumental Genitive in (19), argumental Dative in (20) and possessive Genitive in (21).

$\begin{array}{lll}\text { distrugerea } & \text { oraşului } & \text { / unui oraș } \\ \text { destruction.DET.DEF } & \text { city.DET.DEF.GEN } & \text { a.GEN city } \\ \text { 'the destruction of the/a city' } & \end{array}$

Am dat bani regelui /unui rege

have given money king.DET.DEF.DAT a.DAT king

'We gave money to the/a king'
(21) fata
regelui
/unui rege
daughter. DET.DEF king.DET.DEF.GEN
'the daughter of the/a king'
a.GEN king

With bare nominals, either singular (22) or plural (23), case cannot be marked in the absence of a D. The nominal expression needs, then, to be introduced inside a PP. Preposition $d e$ 'of' maps with the Genitive and preposition la 'at' with the Dative:

(22) a. fată de oameni săraci daughter of people poor

'a poor people's daughter'

b. am dat bani la săraci

have given money to poor

'We gave money to poor people' (meaning: charity to the poor)

(23) a. fată de rege

daughter of king

'daughter of a king / a king's daughter'

b. am dat bani la rege

have given money to king

'we gave money to king' (meaning: we paid our royal taxes) 
Accordingly, the distribution of the Genitive in deverbal -tor nominals is no longer surprising but instead somewhat expected. The absence of Genitive with dispositional agent -tor nominals follows from two factors: (i) non-specificity of the internal argument, which is realized as a bare nominal, and (ii) the impossibility to mark case on bare nominals. Consequently, the bare internal argument in dispositional agent nominals has to be introduced in a de-PP. The grammar of Romanian offers no other option:

$$
\begin{aligned}
& \text { vânzător.ul de mașini } \\
& \text { seller.DET.DEF of cars } \\
& \text { 'the car-seller' }
\end{aligned}
$$

Episodic agent nominals are different because they involve a specific internal argument realized as a full DP, which licenses Genitive case marking. The specific internal DP argument, marked with Genitive, necessarily leads to an episodic reading.

$$
\begin{aligned}
& \text { vânzător.ul maşinii } \\
& \text { seller.DET.DEF } \\
& \text { 'the seller of the car' }
\end{aligned}
$$

The connection between specific DPs and Genitive case is obvious with proper names like Bucharest in (26) or Mona Lisa in (27), which are by default specific, and can only take Genitive, like elsewhere marked on D:

$$
\begin{array}{ll}
\text { distrugerea (frecventa a ) Bucureștiului } & / * \text { de București } \\
\text { destruction-the frequent GEN Bucharest.DET.DEF.GEN } & \text { of Bucharest } \\
\text { 'the frequent destruction of Bucharest' } &
\end{array}
$$

$$
\begin{array}{lll}
\text { vânzătorul } & \text { Mona Lisei } & / * \text { de Mona Lisa } \\
\text { seller-the } & \text { Mona Lisa.DET.GEN } & \text { of Mona Lisa }
\end{array}
$$

'the seller of Mona Lisa'

So, even though episodic agents take Genitives, because they involve specific arguments, and dispositional agents take argumental $d e$-PPs, because they involve nonspecific arguments, both are AS-Ns. The eventive reading, demonstrated by the compatibility with BAs in dispositional agent nominals, corroborates the argumental nature of bare plural de-PPs.

(28) Un mare vânzător de mașini ne-a făcut o ofertă.

a big seller of cars us-has made an offer

'A car-seller who sells a lot of cars made us an offer'.

(29) Un mare vânzător al acestor mașini americane ne-a făcut o ofertă a big seller GEN these.GEN car.GEN american us-has made a offer 'A seller who sold a lot of these american cars made us an offer'. 
The distribution of Genitives is, thus, not only expected, but could also be taken as further support for Roy and Soare's claim that specificity of the internal argument is the source of the episodic/dispositional contrast in agent nominals.

Together with argumental Genitives, Romanian has clear cases of argumental PPs, similar to French. The only difference between the two languages is that all arguments are PPs in French, while it is the case only for non-specific ones in Romanian. In the next section, we further address the nature of argumental PPs.

\section{Argumental PPs in AS-Ns}

Romanian argumental PPs are not restricted to the cases at hand here, namely dispositional agent nominals, but are, in actuality, found in all deverbal AS-Ns when the argument is realized by a bare nominal. Examples (30) and (31) illustrate the same constraint with event denoting deverbal nominals:

$$
\begin{aligned}
& \text { distrugerea (frecventa a) oraşelor } \\
& \text { destruction-the frequent GEN cities.GEN } \\
& \text { ok: 'the (frequent) destruction of the cities' } \\
& \text { \#: 'the (frequent) destruction of cities' }
\end{aligned}
$$

$$
\begin{aligned}
& \text { distrugerea (frecventa) de orașe } \\
& \text { destruction-the frequent of cities } \\
& \text { \#: 'the (frequent) destruction of the cities' } \\
& \text { ok: 'the (frequent) destruction of cities' }
\end{aligned}
$$

We observe not only the existence of argumental PPs in both agent-denoting and eventdenoting AS-Ns but also that they appear under the same conditions, namely with bare nominals, for reasons that we have explained above.

Following Dobrovie-Sorin \& Giurgea (2015), bare nominal arguments have a special status in Romanian as pseudo-incorporated phrases ${ }^{6}$. Pseudo-incorporated arguments exhibit a set of distinctive properties. Interpretationally, (i) they have a tighter than usual relationship to the $(\mathrm{V})$ head, as if they were contributing to the description of the predicate - they are sometimes called co-predicates; (ii) they cannot have a strong/specific interpretation (Massam 2001, Dayal 2003, Dobrovie Sorin et al 2005, 2006); (iii) they are number neutral, in the sense that morphological number does not entail semantic singularity/plurality. Structurally, (iv) they always appear adjacent to the head; (v) they can be coordinated (Massam 2001); and (vi) they generally lack Case (Mithun 1984; van Geenhoven 1998; Dayal 2003; Massam 2001).

Some of these properties are reminiscent of our $d e$-PP arguments: non-specificity, absence of Case. Others will be discussed below. Still, the question whether pseudoincorporated arguments exist in the structure of derived nominals has seldom been addressed in the literature and never for Romanian. The only work that we know of is Knittel (2010) which discusses bare arguments of event-denoting AS-Ns in French (e.g.,

6 Pseudo-incorporation exhibits similar properties to head-to-head incorporation, but concerns phrasal arguments rather than heads (Massam 2001, Dayal 2003, Dobrovie-Sorin et al 2005, 2006 among others). 
vente 'sale', destruction 'destruction'). Knittel (2010) argues that the bare arguments of event-denoting AS-Ns, which are introduced by a P head, are pseudo-incorporated. The analysis is supported by a series of properties that bare PPs exhibit with respect to scope, number neutrality, adjacency, coordination and non-specificity. For instance, example (32a) shows that bare complements have to be adjacent to the $\mathrm{N}$ head, contrary to what happens with determined complements (32b). In (32a), bijoux 'jewels' is non-specific, non determined (bare plural - and note that bare nominals are rare in French and only possible under government of a $\mathrm{V}$ or $\mathrm{P}$ head (e.g., avoir faim (lit. have hunger) 'be hungry', en vacances (lit. in vacations) 'in vacation'), and exhibits a low level of individuality (number neutral-morphological plural does not entail that the sale had to involve more than one jewels):

a. une vente de bijoux à domicile / ??à domicile de bijoux a sale of jewels at home at home of jewels 'a door-to-door jewelry sale / *a jewelry door-to-door sale'

b. La construction intensive de ces maisons a occasionné du bruit. the building intensive of these houses has caused DET noise 'The intensive building of these houses has provoked noise.'

In fact, pseudo-incorporated PPs have also been argued for, in French, in the case of bare arguments under phrasal negation (Mathieu 2006). In French, indefinite count DPs (un bijou 'a jewel', une réponse 'an answer') and partitive mass DPs (du rythme 'rhythm', de l'eau 'water') become de-PPs in the context of negation (33). Such de-PP arguments exhibit a low degree of individuality, are interpreted as non-specific, and must be adjacent to the V head (Mathieu 2006):
a. Je n'ai pas vendu (*souvent) de bijoux.
I not-have NEG sold often of jewels
'I haven't sold any jewels / I sold no jewels'.
b. Il n'y a pas (*souvent) de réponse / d'eau / de rythme
There not-is NEG often of answer of.water of rhythm
'There is no answer' / 'There is no water' / 'There is no rhythm'

Turning back to Romanian agent nominals, evidence points to the pseudoincorporated status of $d e$-PPs in dispositional agent AS-Ns. The first two properties already mentioned are non-specificity and absence of Case. By definition, dispositional agent nominals are the ones that involve weak/non-specific internal arguments: the nonspecificity of the (verbal) argument is inherited by the derived nominal, and this leads to the dispositional interpretation at the DP level for dispositional agent nominals. These bare arguments cannot bear Case, here Genitive Case, which is, as we already know, exactly what distinguishes arguments of episodic agent nominals from arguments of dispositional agent nominals.

Moreover, as shown by Knittel (2010) for event-denoting AS-Ns in French, dePP arguments in dispositional agent nominals are necessarily adjacent to the nominal head (34). Interpretationally, and as expected, $d e$-PP arguments exhibit also number neutrality: the plural on bijuterii 'jewels' in (34) does not entail plurality of selling events / sold jewels. 
(34) un vânzător de bijuterii la domiciliu / *un vânzător la domiciliu de bijuterii a seller of jewels at home a seller at home of jewels. 'a door-to door jewelry seller' *'a jewelry door-to-door seller'

Finally, we note that coordination, as a further property of pseudo-incorporated arguments (Massam 2001), is possible with these arguments at the $\mathrm{N}$ level (i.e., de outscopes the coordination), indicating a defective nominal structure. As a matter of fact, the property is shared with pseudo-incorporated bare arguments in the verbal domain as well (36):

$$
\begin{aligned}
& \text { un vânzător de bijuterii și (de) tablouri } \\
& \text { a seller of jewels and (of) paintings } \\
& \text { 'a seller of jewels and paintings' }
\end{aligned}
$$

(36) a vândut bijuterii și tablouri

has sold jewels and paintings

'He/She has sold jewels and paintings'.

Unsurprisingly, a similar analysis straightforwardly extends to event-denoting AS-Ns in Romanian as well. Consider, for instance, example (37) which illustrates adjacency, non-specificity, and coordination. The low level of individuality is the same as elsewhere with bare PP arguments:
a. vânzarea de bijuterii la domiciliu / *la domiciliu de bijuterii sale-the of jewels at home at home of jewels 'the sale of jewels at home'
b. vânzarea de bijuterii și tablouri sale-the of jewels and paintings 'the sale of jewels and paintings'

So, if this is correct, bare nominal arguments in AS-Ns are similar to bare arguments of $\mathrm{V}$ in the verbal domain. This means that the pseudo-incorporation analysis is on the right track: it is the properties of the nominals themselves (namely, the fact that they are non-specific and structurally defective) that trigger their distinctive syntactic behavior as pseudo-incorporated.

It follows from the discussion that there is a close relationship between the properties of the internal argument and the semantic/syntactic internal properties of the derived nominal. This proposal, first made in Roy \& Soare $(2013,2014,2020)$, is largely confirmed here: non-specificity, number neutrality, and absence of case are correlated. Furthermore, non-specificity as the source of the dispositional reading now becomes transparent: number neutrality and a low-degree of individuality of non-specific arguments induces neutrality of derived nominals with respect to event pluractionality, and hence brings about the dispositional rather than episodic interpretation. 


\section{Conclusion: Romanian and beyond}

To conclude, Romanian shows that, in both event-denoting and agent-denoting AS-Ns, specificity of internal arguments correlates with case marking; while non-specific bare arguments are pseudo-incorporated. In the case of -tor derived nominals, specificity of the internal argument derives both the episodic reading and case properties. In turn, the lack of specificity in bare arguments of dispositional -tor nominals derives absence of case marking, linked to pseudo-incorporation. Number neutrality in non-specific arguments brings about the dispositional interpretation. This opens a new dimension in the direct relationship between specificity of the internal argument, the interpretation of derived AS-Ns, and their internal structure.

Putting together these results with Knittel (2010), and previous discussion of French in Roy \& Soare $(2013,2014)$, the extension of this analysis to French agentdenoting deverbal nominals appears highly desirable. Properties of Romanian bare arguments (cf., 34) replicate in French as well: non-specificity, number neutrality, adjacency, and obviously absence of case (38). Non-specific de-PPs in dispositional agent -eur nominals are pseudo-incorporated arguments:

(38) un vendeur de bijoux à domicile / *un vendeur à domicile de bijoux a seller of jewels at home a seller at home of jewels. 'a door-to door jewelry seller' *'a jewelry door-to-door seller'

In turn, pseudo-incorporation is not a tenable analysis for specific argumental DPs in episodic agent -eur nominals, for reasons already stated. If a clear parallel exists with Romanian, which seems to be the case at every level of comparison so far, specific dePPs are true Genitives, in line with Milner (1982), Zribi-Hertz (2003) and Knittel (2010). By the same token, this would mean that French de-PPs, that are commonly seen as multiply ambiguous in the grammar of French, are also ambiguous in agent and instrument - eur nominals. They express: (i) Genitive case marked DPs with episodic ASNs, (ii) pseudo-incorporated arguments in dispositional AS-Ns, and (iii) modifiers in non argument-supporting instruments (R-Ns). The only difference between Romanian and French, thus, is morphological:

i. Episodic AS-Ns

ii. Dispositional AS-Ns

iii. Instrument R-Ns
Romanian / French

Genitive (Case/de)

$d e$-PP (pseudo incorporated arguments)

de-PP (modifiers)

In closing, let us turn to English, and the partition between phrasal agents (saver of lives, cutter of branches), compound agents (lifesaver, branch cutter) and (compound) instruments (branch cutter). Whether this partition can similarly be reduced to the threeway distinction between episodic agents, dispositional agents, and instruments is a pertinent question. A number of possible similarities and potential problems arise, which we will briefly expose here. First, compound agents are always dispositional - they do not entail any specific event (cf., Rappaport Hovav \& Levin 1992, Alexiadou \& Schäfer 2010). Compounding is a form of incorporation, a morphological process which shares properties with pseudo-incorporation. However, this basic similarity does not discriminate compounds from phrasal formations: while phrasal agent nominals entail an 
underlying event, it is not clear whether this event is a specific or non-specific one. In addition, and contributing presumably to the issue, phrasal agent nominals take bare plurals: e.g., saver of lives and not \#saver of these/the lives. Bare plurals are non specific, and therefore some, or maybe all, phrasal agent nominals should receive a dispositional interpretation.

Second, the status of agent-denoting -er nominals as AS-Ns is debatable, and in fact has been contested by Borer (2013). Importantly, English, as opposed to Romanian and French, rarely allows specific arguments altogether: e.g., \#the seller of the house, \#the reader of the book, \#the builder of the bridge, etc., but note the existence of the director of the department, the leader of the crowd, the owner of the painting). It also never allows indirect arguments even when they are specific: e.g., *the reader of the book to the children, (compared to French, e.g., le conteur de l'histoire aux enfants (lit. the teller of the story to the children) and Romanian with a Dative argument, e.g., aducătorul acestei scrisori destinatarului (lit. the carrier of this letter recipient.DAT)).

Third, we note intriguing similarities with regard to instruments. In the three languages, independently of their morphological form, instruments cannot be construed with specific DPs: specific modifiers in French (e.g., un broyeur de végétaux / \#des végétaux (lit. a shredder of plants / \# of the plants) and Romanian (un tocător de vegetale /\#vegetalelor (lit. a shredder of plants / \#of the plants), and in synthetic compounds in English (e.g., a (*this) plant-shredder). In English, the ban on full specific DPs is explainable by compounding. In French and Romanian, however, the restriction is much more opaque as nothing should in principle prevent specific PP modifiers from occurring with instruments. So, it is possible that something more general is happening that also blocks instruments in phrasal formations in English. The question why phrasal nominals can never be interpreted as instruments, even though phrasal -er nominals take bare plurals, is an open question. It also potentially relates to the fact that instruments cannot be AS-Ns in French and Romanian, in ways that remain to be understood.

We will leave a full analysis of English and the cross-linguistic constraints on instruments open for further research.

\section{References}

Alexiadou, Artemis and Florian Schäfer. 2008. Instrumental -er Nominals Revisited, in: Online Proceedings of WCCFL 27 Poster Session. UCLA.

Alexiadou, Artemis and Florian Schäfer. 2010. On the syntax of episodical vs. dispositional -er nominals. In A. Alexiadou and M. Rathert (eds.) Nominalizations across Languages and Frameworks. Berlin/New York, Mouton de Gruyter.

Borer, Hagit. 2013. Taking Form: Structuring Sense, Vol. III. Oxford: Oxford University Press.

Chomsky, Noam 1970. Remarks on Nominalizations. In R. Jacobs and P. Rosenbaum (eds.), Readings in English Transformational Grammar. Waltham, MA: Blaisdell: 184-221. 
Dayal, Veneeta. 2003. A semantics for pseudo-incorporation. Manuscript, Rutgers University.

Dobrovie-Sorin, Carmen, Tonia Bleam and Maria Teresa Espinal. 2005. Noms nus, nombre et types d'incorporation. In C. Dobrovie-Sorin (ed.) Généricité et détermination nominale, Presses Universitaires de Vincennes: 129-157.

Dobrovie-Sorin, Carmen, Tonia Bleam and Maria Teresa Espinal. 2006. Bare nouns, number and types of incorporation. In L. Tasmowski and S. Vogeleer (eds.), Nondefiniteness and plurality, Amsterdam, Philadelphia: John Benjamins: 51-79.

Dobrovie-Sorin Carmen and Ion Giurgea. 2015. Weak reference and Property Denotation. Two types of pseudo-incorporated bare nominals. Syntax and Semantics 40: 88-125.

Geenhoven, Veerle van. 1998. Semantic incorporation and indefinite descriptions: Semantic and syntactic aspects of noun incorporation in West Greenlandic. Stanford: CSLI.

Grimshaw, Jane 1990. Argument Structure. MIT Press.

van Hout, Angeliek and Thomas Roeper. 1998. Events and aspectual structure in derivational morphology. In Harley, H. (ed.), Papers from the Upenn/MIT Roundtable on Argument Structure and Aspect, vol.32 of MIT Papers in Linguistics. Cambridge, Mass: 175-200.

Knittel, Marie-Laurence. 2010. Possession vs. pseudo-incorporation in the nominal domain, Linguistic Review 27: 177-230.

Massam Diane. 2001. Pseudo-incorporation in Niuean. Natural language and linguistic theory 19: 153-197.

Mathieu, Eric. 2006. Bare nouns and morpho-syntactic reflexes of semantic incorporation: Some new facts. In L. Bateman and C. Ussery (eds), Proceedings of the Thirty-Fifth Annual Meeting of the North East Linguistic Society (NELS 35), Charleston: Book Surge Publishing: 403-418.

McIntyre, Andrew. 2014. Constraining Argument Structure in Nominalizations: The Case of English -Er. Lingua 141: 1.

Milner, Jean-Claude. 1982. Ordres et raisons de langue. Paris, Seuil.

Mithun, Marianne. 1984. The evolution of noun incorporation. Language 60: 847-893.

Rappaport Hovav, Malka and Beth Levin. 1992. - er Nominals: Implications for a Theory of Argument Structure. In T. Stowell and E. Wehrli, eds., Syntax and Semantics 26: Syntax and the Lexicon, Academic Press, New York, NY: 127-153. 
Roy, Isabelle, Bridget Copley, Saveria Colonna and Sudha Arunachalam. 2016. "Grammatical and conceptual knowledge of dispositions in the interpretation of -er nominals: Experimental evidence. In Martin, F., M. Pitteroff and T. Pross (eds), Morphological, Syntactic and Semantic Aspects of Dispositions, SinSpec series of the SFB732, University of Stuttgart: 92-106.

Roy, Isabelle and Elena Soare. 2013. Event related nominals. In G. Iordăchioaia, I. Roy and K. Takamine (eds.) Categorization and Category Change. Cambridge Scholars Publishing, NewCastle upon Tyne: 123-152.

Roy, Isabelle and Elena Soare. 2014. "On the internal event properties of -er nominals." Lingua, 141: 139-156.

Roy, Isabelle and Elena Soare. 2020. Agent and other function nominals in a neoconstructionist approach to nominalizations. In Alexiadou, A. and H. Borer (eds.), Nominalization. 50 Years from Chomsky's Remarks. Oxford University Press: 309336.

Zribi-Hertz, Anne. 2003. La syntaxe de l'article défini : de la structure à l'interprétation. Paper presented at the Modèles Syntaxiques Conference. Brussels, 6-8 March 2003. 